\title{
The association between serum albumin and LOS of patients with acute heart failure: a retrospective study based on the MIMIV-IV database
}

Tao Liu

Xuzhou Medical University Affiliated Hospital

haochen xuan

Xuzhou Medical University Affiliated Hospital

lili wang

Xuzhou Medical University Affiliated Hospital

xiaoqun li

Xuzhou Medical University Affiliated Hospital

zhihao lu

Xuzhou Medical University Affiliated Hospital

zhaoxuan tian

Xuzhou Medical University Affiliated Hospital

junhong chen

Xuzhou Medical University Affiliated Hospital

chaofan wang

Xuzhou Medical University Affiliated Hospital

dongye li

Xuzhou Medical University Affiliated Hospital

tongda xu ( $\square$ xutongda3004@163.com )

Xuzhou Medical University Affiliated Hospital https://orcid.org/0000-0002-5594-3992

\section{Research}

Keywords: serum albumin, length of stay, acute heart failure, intensive care unit

Posted Date: August 31st, 2021

DOI: https://doi.org/10.21203/rs.3.rs-850487/v1

License: (c) (i) This work is licensed under a Creative Commons Attribution 4.0 International License. Read Full License 


\section{Abstract}

Objective: To assess the relationship between serum albumin and length of stay (LOS) of the intensive care unit (ICU).

Design and Participants: we retrospectively analyze 2280 patients with acute heart failure(AHF) from the medical information mart for intensive care IV (the MIMIC-IV) database.

Materials and Methods: The exposure variable of the present study was serum albumin. The outcome variable was LOS. The final models were established by multivariate linear regression, and subgroup analysis was performed. Trend test and smooth fitting curves were used to evaluate the association between serum albumin and LOS.

Results: When the value of serum albumin was less than $5.1 \mathrm{~g} / \mathrm{dl}$, the analysis of 2280 patients showed that the linear relationship between albumin and LOS. LOS was gradually shortened with the albumin increasing ( $\beta$ : $-0.636 ; 95 \% \mathrm{Cl}:-0.819,-0.453 ; P<0.001)$. In

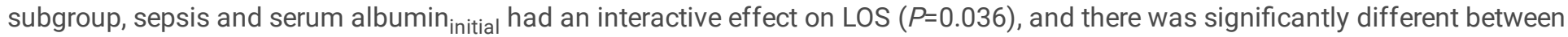
AHF patients with sepsis ( $\beta:-1.927 ; 95 \% \mathrm{Cl}:-3.823,-0.030)$ and without $\operatorname{sepsis}(\beta:-1.412 ; 95 \% \mathrm{Cl}:-1.737,-1.087)$.

Conclusion: When serum albumin was less than $5.1 \mathrm{~g} / \mathrm{dl}$, the negative association was presented between serum albumin level and LOS among patients with AHF, and this association is even closer in patients with sepsis.

\section{Introduction}

As a common and growing medical problem, heart failure(HF) is one of the most frequent causes of admission and hospital mortality.[1] The limitation of options for the management of patients with HF lead to long length of stays (LOS). Especially, some patients with acute heart failure (AHF) in the intensive care unit (ICU) might have many underlying diseases, which might lead to long LOS. As a major problem of cardiovascular disease, AHF not only seriously affects the quality of life of patients, but also weighs their economic burden. Therefore, it is essential for us to pay more attention to LOS.

As an inexpensive and powerful indicator, serum albumin is an essential protein in the human body produced by liver, and often used to evaluate the prognosis of a variety of diseases, such as HF, acute pulmonary embolism, diabetic nephropathy and patients with severe illness in ICU.[2-5] Previous studies had shown that serum albumin was a powerful indicator to short-term and longterm prognosis of patients with HF, high albumin levels would significantly reduce their hospital mortality and rehospitalization.[68] Hypoalbuminemia often occurs in ICU,[9] and it is closely related to the long LOS. However, there were few studies on whether serum albumin level affects LOS in patients with AHF, especially, a specific association was not revealed between albumin level and LOS of patients with AHF. Thus, it is difficult to apply albumin level as a predictive indicator for LOS of patients with AHF to clinical practice.

Therefore, it is necessary to reassess the relationship between serum albumin and LOS in patients with AHF. In the present study, we analyzed the association between serum albumin level and LOS of patients with AHF from the medical information mart for intensive care IV (the MIMIC-IV ) database, and we conducted a subgroup analysis of the relationship between serum albumin levels and LOS under different age, genders, malignancy, liver cirrhosis, nephrotic syndrome, chronic kidney disease and sepsis. In particular, the trend relationship between albumin level and LOS was explained.

\section{Materials And Methods}

\subsection{Study population}

2280 AHF patients whose years more than 18 were enrolled from the MIMIC-IV database (AHF icd_code $=42821,42823,42831$, $42833,42841,42843,15021,15023,15031,15033,15041,15043,150811,150813$ ) in our study. The data provided by the above database was the original data. Thus, data used for the study was retrieved from MIMIC-IV by author Liu (ID: 9008147, Supplemental Table S1.), who had completed the online training course of the National Institutes. The selection process of study participants is shown in Fig. 1.

\subsection{Variables}


The exposure variable of the present study was initial albumin (albumin initial $_{1}$ ), minimum serum albumin (albumin min $_{\text {) }}$ and maximum

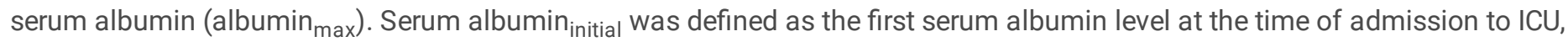
serum albumin $_{\min }$ was defined as minimum albumin level during ICU, serum albumin $\max _{\text {ax }}$ was defined as maximum albumin level during ICU. The outcome variable was LOS of ICU. Categorical variables [including gender, ethnicity, insurance, comorbidities and drugs use] and continuous variables [including age, systolic blood pressure (SBP), diastolic blood pressure (DBP) and body mass index (BMI)] were analyzed in the present study (Table 1). 
Table 1

Baseline characters comparsion among the different LOS of patients with acute heart failure in ICU

\begin{tabular}{|c|c|c|c|c|c|}
\hline \multirow[t]{2}{*}{ Variables } & $<2.14$ days & $\begin{array}{l}2.14 \leq \text { to }<3.67 \\
\text { days }\end{array}$ & $\begin{array}{l}3.67 \leq \text { to }<5.31 \\
\text { days }\end{array}$ & $\geq 5.31$ days & \multirow[t]{2}{*}{$\begin{array}{l}P \\
\text { value }\end{array}$} \\
\hline & $(N=570)$ & $(N=570)$ & $(N=570)$ & $(N=570)$ & \\
\hline Age, years & $\begin{array}{l}70.51 \pm \\
13.22\end{array}$ & $70.81 \pm 13.99$ & $69.71 \pm 13.37$ & $\begin{array}{l}68.47 \pm \\
14.19\end{array}$ & 0.024 \\
\hline Male, n(\%) & $\begin{array}{l}307 \\
(53.86 \%)\end{array}$ & $317(55.61 \%)$ & 333 (58.42\%) & $\begin{array}{l}338 \\
(59.30 \%)\end{array}$ & 0.222 \\
\hline Ethnicity, n(\%) & & & & & 0.013 \\
\hline Whites & $\begin{array}{l}387 \\
(67.89 \%)\end{array}$ & $404(70.88 \%)$ & $373(65.44 \%)$ & $\begin{array}{l}383 \\
(67.19 \%)\end{array}$ & \\
\hline Black & $65(11.40 \%)$ & $46(8.07 \%)$ & $47(8.25 \%)$ & $38(6.67 \%)$ & \\
\hline Other & $\begin{array}{l}118 \\
(20.70 \%)\end{array}$ & $120(21.05 \%)$ & $150(26.32 \%)$ & $\begin{array}{l}149 \\
(26.14 \%)\end{array}$ & \\
\hline SBP, mmHg & $\begin{array}{l}115.34 \pm \\
19.73\end{array}$ & $114.55 \pm 20.26$ & $114.62 \pm 21.43$ & $\begin{array}{l}116.81 \pm \\
21.57\end{array}$ & 0.379 \\
\hline DBP, mmHg & $\begin{array}{l}58.20 \pm \\
15.07\end{array}$ & $56.77 \pm 14.50$ & $57.37 \pm 16.87$ & $\begin{array}{l}59.01 \pm \\
19.22\end{array}$ & 0.382 \\
\hline $\mathrm{BMI}, \mathrm{kg} / \mathrm{m}^{2}$ & $28.93 \pm 6.56$ & $28.98 \pm 6.23$ & $29.39 \pm 6.31$ & $29.18 \pm 6.78$ & 0.529 \\
\hline Insurance, n(\%) & & & & & 0.12 \\
\hline Medicare & $\begin{array}{l}320 \\
(56.14 \%)\end{array}$ & 332 (58.25\%) & 317 (55.61\%) & $\begin{array}{l}299 \\
(52.46 \%)\end{array}$ & \\
\hline Medicaid & $34(5.96 \%)$ & $25(4.39 \%)$ & $37(6.49 \%)$ & $23(4.04 \%)$ & \\
\hline Other & $\begin{array}{l}216 \\
(37.89 \%)\end{array}$ & $213(37.37 \%)$ & $216(37.89 \%)$ & $\begin{array}{l}248 \\
(43.51 \%)\end{array}$ & \\
\hline \multicolumn{6}{|l|}{ Comorbidities } \\
\hline Diabetes, n(\%) & $\begin{array}{l}106 \\
(18.60 \%)\end{array}$ & $129(22.63 \%)$ & $97(17.02 \%)$ & $\begin{array}{l}103 \\
(18.07 \%)\end{array}$ & 0.082 \\
\hline Hypertension, n(\%) & $23(4.04 \%)$ & 29 (5.09\%) & $16(2.81 \%)$ & $32(5.61 \%)$ & 0.099 \\
\hline $\begin{array}{l}\text { Chronic obstructive pulmonary disease, } \\
\mathrm{n}(\%)\end{array}$ & $54(9.47 \%)$ & $62(10.88 \%)$ & $66(11.58 \%)$ & $71(12.46 \%)$ & 0.431 \\
\hline Respiratory failure, n(\%) & $\begin{array}{l}114 \\
(20.00 \%)\end{array}$ & $171(30.00 \%)$ & $223(39.12 \%)$ & $\begin{array}{l}279 \\
(48.95 \%)\end{array}$ & $<.001$ \\
\hline Malignancy, n(\%) & $3(0.53 \%)$ & $3(0.53 \%)$ & $2(0.35 \%)$ & $3(0.53 \%)$ & 0.965 \\
\hline Atrial fibrillation, $\mathrm{n}(\%)$ & $\begin{array}{l}293 \\
(51.40 \%)\end{array}$ & 304 (53.33\%) & $310(54.39 \%)$ & $\begin{array}{l}319 \\
(55.96 \%)\end{array}$ & 0.472 \\
\hline Acute myocardial infarction, $\mathrm{n}(\%)$ & $71(12.46 \%)$ & $85(14.91 \%)$ & $86(15.09 \%)$ & $78(13.68 \%)$ & 0.547 \\
\hline Liver cirrhosis, n(\%) & $14(2.46 \%)$ & $11(1.93 \%)$ & $7(1.23 \%)$ & $12(2.11 \%)$ & 0.492 \\
\hline Chronic kidney disease, n(\%) & $\begin{array}{l}215 \\
(37.72 \%)\end{array}$ & $210(36.84 \%)$ & $239(41.93 \%)$ & $\begin{array}{l}229 \\
(40.18 \%)\end{array}$ & 0.277 \\
\hline Nephrotic syndrome, n(\%) & $5(0.88 \%)$ & $8(1.40 \%)$ & $1(0.18 \%)$ & $1(0.18 \%)$ & 0.025 \\
\hline Sepsis, $n(\%)$ & $25(4.39 \%)$ & $29(5.09 \%)$ & $45(7.89 \%)$ & $49(8.60 \%)$ & 0.007 \\
\hline
\end{tabular}




\begin{tabular}{|c|c|c|c|c|c|}
\hline \multirow[t]{2}{*}{ Variables } & $<2.14$ days & $\begin{array}{l}2.14 \leq \text { to }<3.67 \\
\text { days }\end{array}$ & $\begin{array}{l}3.67 \leq \text { to }<5.31 \\
\text { days }\end{array}$ & $\geq 5.31$ days & \multirow[t]{2}{*}{$\begin{array}{l}P \\
\text { value }\end{array}$} \\
\hline & $(N=570)$ & $(N=570)$ & $(N=570)$ & $(N=570)$ & \\
\hline Nitroglycerin, n(\%) & $\begin{array}{l}360 \\
(63.16 \%)\end{array}$ & $334(58.60 \%)$ & $320(56.14 \%)$ & $\begin{array}{l}292 \\
(51.23 \%)\end{array}$ & $\hat{0}_{0.001}$ \\
\hline Diuretics, n(\%) & $\begin{array}{l}554 \\
(97.19 \%)\end{array}$ & $552(96.84 \%)$ & $549(96.32 \%)$ & $\begin{array}{l}548 \\
(96.14 \%)\end{array}$ & 0.747 \\
\hline$\beta$ blocker, $n(\%)$ & $\begin{array}{l}496 \\
(87.02 \%)\end{array}$ & $490(85.96 \%)$ & $491(86.14 \%)$ & $\begin{array}{l}491 \\
(86.14 \%)\end{array}$ & 0.955 \\
\hline Cardiotonic drugs, $\mathrm{n}(\%)$ & $\begin{array}{l}111 \\
(19.47 \%)\end{array}$ & $146(25.61 \%)$ & $174(30.53 \%)$ & $\begin{array}{l}196 \\
(34.39 \%)\end{array}$ & $\hat{0}_{0.001}$ \\
\hline Albumin $_{\text {initial }}$ & $3.67 \pm 0.60$ & $3.51 \pm 0.59$ & $3.37 \pm 0.61$ & $3.30 \pm 0.64$ & $\begin{array}{l}< \\
0.001\end{array}$ \\
\hline Albumin $_{\max }$ & $3.88 \pm 0.56$ & $3.76 \pm 0.57$ & $3.72 \pm 0.57$ & $3.66 \pm 0.62$ & $\hat{0.001}$ \\
\hline Albumin $_{\min }$ & $3.37 \pm 0.64$ & $3.24 \pm 0.62$ & $3.06 \pm 0.61$ & $3.04 \pm 0.62$ & $\hat{0}_{0.001}$ \\
\hline \multicolumn{6}{|c|}{ 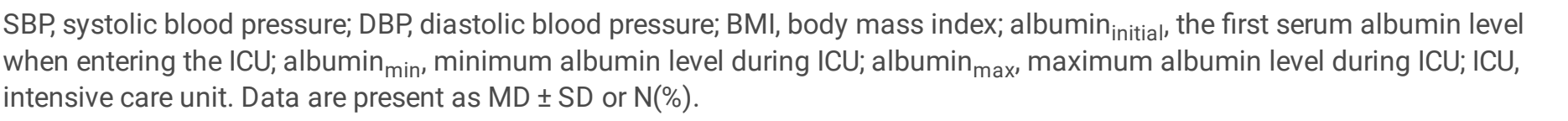 } \\
\hline
\end{tabular}

\subsection{Statistical analysis}

Continuous variables were represented by mean \pm standard deviation or median (25th quartile, 75th quartile) in the table. If the test of normality and the homogeneity test of variance are performed, the T test is appropriate, otherwise, the Kruskal Wallis test is appropriate. Categorical variables are presented as a percentage in the tables and compared using the $X^{2}$ test. Multivariate linear regression with significant difference of 0.05 was used to build the final models. The subgroup analysis was performed by stratified multivariate linear regression analysis under different age, genders, nephrotic syndrome, malignancy, liver cirrhosis, nephrotic syndrome, chronic kidney disease and sepsis. Trend test and smooth fitting curves were used to evaluate the association between serum albumin level and LOS. All statistical analyses were performed using the software Stata15. All $P$ value $<0.05$ was significant.

\section{Results}

\subsection{Baseline characteristics}

The mean age of 2280 patients were $69.88 \pm 13.72$, and men made up $56.80 \%$ of the total. All patients were grouped by the quartile range of $\operatorname{LOS}\left(<2.14\right.$ days; $2.14 \leq$ to $<3.67$ days; $3.67 \leq$ to $<5.31$ days; $\geq 5.31$ days) during the ICU (Table 1). albumin initial, $_{\text {, }}$ albumin $_{\max }$ and albumin $_{\min }$ in the quartile grouping of LOS had significant difference. Except age, ethnicity, respiratory failure, nephrotic syndrome, sepsis, nitroglycerin, cardiotonic drugs $(P<0.05)$, all variables were not significant in other subgroups $(P>$ 0.05). Comparison of baseline characteristics among albumin level was provided in Supplemental Table S2.

\subsection{Analysis of association between serum albumin initial $_{\text {and LOS }}$}

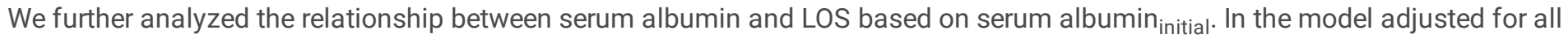

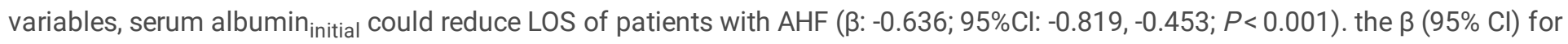
LOS across the albumin quartile were $-0.611(-0.925,-0.298),-0.722(-1.056,-0.388)$, and $-1.117(-1.441,-0.792)$, compared with the first quartile of albumin ( $P$ for trend $<0.001$ ). Both unadjusted and adjusted only age, gender, and ethnicity models showed statistical similar significance to the above. (Table 2). The analysis of the relationship between serum albumin and LOS based on serum albumin $_{\max }$ and serum albumin $\min _{\text {was provided in Supplemental Table S3. }}$ 
Table 2

Association of serum albumininitial with length of stay in ICU

\begin{tabular}{|c|c|c|c|}
\hline \multirow[t]{2}{*}{ Variables } & Model 1 & Model 2 & Model 3 \\
\hline & $\beta(95 \% \mathrm{Cl})$ & $\beta(95 \% \mathrm{Cl})$ & $\beta(95 \% \mathrm{Cl})$ \\
\hline Albumin & $-0.873(-1.048,-0.699)^{\star \star \star}$ & $-0.872(-1.047,-0.697)^{\star \star \star}$ & $-0.636(-0.819,-0.453)^{\star \star \star}$ \\
\hline \multicolumn{4}{|l|}{ Quartile of albumin $_{\text {initial }}$} \\
\hline Q1 (<3.0 g/dl), (Ref.) & Ref. & Ref. & Ref. \\
\hline Q2 $(3.0 \leq$ to $<3.5 \mathrm{~g} / \mathrm{dl})$ & $-0.805(-1.120,-0.490)^{\star \star \star}$ & $-0.800(-1.114,-0.485)^{\star \star \star}$ & $-0.611(-0.925,-0.298)^{\star \star \star}$ \\
\hline Q3 $(3.5 \leq$ to $<3.9 \mathrm{~g} / \mathrm{dl})$ & $-1.022(-1.351,-0.693)^{\star \star \star}$ & $-1.018(-1.346,-0.690)^{\star \star \star}$ & $-0.722(-1.056,-0.388)^{\star \star \star}$ \\
\hline $\mathrm{Q} 4(\geq 3.9 \mathrm{~g} / \mathrm{dl})$ & $-1.526(-1.838,-1.214)^{\star \star \star}$ & $-1.525(-1.838,-1.213)^{\star \star \star}$ & $-1.117(-1.441,-0.792)^{\star \star \star}$ \\
\hline$P$ for trend & $<0.001$ & $<0.001$ & $<0.001$ \\
\hline \multicolumn{4}{|c|}{ 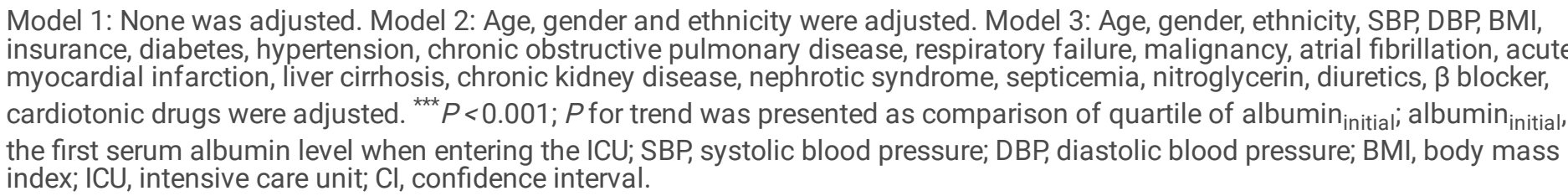 } \\
\hline
\end{tabular}

Figure 2 showed the relationship between albumin ${ }_{\text {initial, }}$ albumin $\max _{\text {and }}$ albumin $\min _{\text {in }}$ and LOS by using smooth fitting curve and scatter plot. Both smooth fitting curve and scatter plot all showed that LOS of patient with AHF was gradually shortened when serum albumin was gradually increased. However, this result was based on the fact that albumin ${ }_{\text {initial, }}$ albumin $_{\max }$ and albumin $_{\min }$

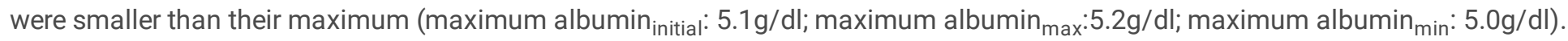

\subsection{Subgroup analysis of association between serum albumin initial $_{\text {and LOS }}$}

The present study based on subgroup analysis of age, genders, malignancy, liver cirrhosis, nephrotic syndrome, chronic kidney disease and sepsis showed the relationship between serum albumin $n_{\text {initial }}$ and LOS. Among subgroups, there was significant trend association between serum albumin initial $_{\text {and LOS. Sepsis and serum albumin }}$ initial had an interactive effect on the LOS (P=0.036). there was significantly different between AHF patients with sepsis $(\beta:-1.927 ; 95 \% \mathrm{Cl}:-3.823,-0.030)$ and without sepsis $(\beta$ : -1.412 ; $95 \% \mathrm{Cl}:-1.737,-1.087)$. Except for the subgroup of sepsis, the interaction of serum albumin $_{\text {initial }}$ in subgroups for age, gender, malignancy, liver cirrhosis, nephrotic syndrome and chronic kidney disease with LOS were no significant (Table 3). 
Table 3

Subgroups analysis for the associations of serum albumininitial with length of stay in ICU

\begin{tabular}{|c|c|c|c|c|c|c|}
\hline \multirow[t]{2}{*}{ Variables } & $\begin{array}{l}\text { Q1(< } \\
3.0 \mathrm{~g} / \mathrm{dl})\end{array}$ & $\mathrm{Q} 2(3.0 \leq$ to $<3.5 \mathrm{~g} / \mathrm{dl})$ & $\mathrm{Q} 3(3.5 \leq$ to $<3.9 \mathrm{~g} / \mathrm{dl})$ & $\mathrm{Q} 4(\geq 3.9 \mathrm{~g} / \mathrm{dl})$ & \multirow[t]{2}{*}{$\begin{array}{l}P \text { for } \\
\text { trend }\end{array}$} & \multirow[t]{2}{*}{$\begin{array}{l}P \text { for } \\
\text { interaction }\end{array}$} \\
\hline & (Ref.) & $\beta(95 \% \mathrm{Cl})$ & $\beta(95 \% \mathrm{Cl})$ & $\beta(95 \% \mathrm{Cl})$ & & \\
\hline Age, years & & & & & & 0.573 \\
\hline$<65$ & Ref. & $-0.411(-1.016,0.193)$ & $-1.029(-1.655,-0.403)^{\star \star}$ & 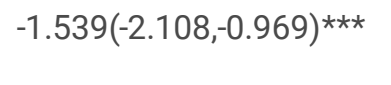 & $\begin{array}{l}< \\
0.001\end{array}$ & \\
\hline$\geq 65$ & Ref. & $-0.964(-1.330,-0.598)^{\star \star \star}$ & $-1.017(-1.401,-0.634)^{\star \star \star}$ & $-1.535(-1.907,-1.163)^{\star \star \star}$ & $\begin{array}{l}< \\
0.001\end{array}$ & \\
\hline Gender & & & & & & 0.708 \\
\hline Male & Ref. & $-0.864(-1.290,-0.438)^{\star \star \star}$ & $-1.023(-1.465,-0.580)^{\star \star \star}$ & $-1.519(-1.936,-1.103)^{\star \star \star}$ & $\begin{array}{l}< \\
0.001\end{array}$ & \\
\hline Female & Ref. & $-0.736(-1.204,-0.269) \star \star$ & $-1.033(-1.524,-0.542)^{\star \star \star}$ & 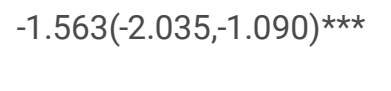 & $<0.001$ & \\
\hline Malignancy & & & & & & 0.202 \\
\hline No & Ref. & $\begin{array}{l}-0.805(-1.121 \\
-0.490)^{\star \star \star}\end{array}$ & $\begin{array}{l}-1.008(-1.338 \\
-0.679)^{\star \star *}\end{array}$ & $\begin{array}{l}-1.518(-1.831 \\
-1.205)^{\star \star *}\end{array}$ & $\begin{array}{l}<.001 \\
0.001\end{array}$ & \\
\hline Yes & Ref. & $-1.673(-7.193,3.847)$ & $-4.782(-9.821,0.257)$ & $-4.582(-9.621,0.457)$ & 0.061 & \\
\hline $\begin{array}{l}\text { Liver } \\
\text { cirrhosis }\end{array}$ & & & & & & 0.953 \\
\hline No & Ref. & $-0.800(-1.119,-0.481)^{\star \star \star}$ & $-1.048(-1.379,-0.717)^{\star \star \star}$ & 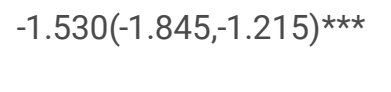 & $\begin{array}{l}< \\
0.001\end{array}$ & \\
\hline Yes & Ref. & $-0.804(-2.855,1.247)$ & $0.660(-2.088,3.408)$ & $-1.642(-4.158,0.873)$ & 0.395 & \\
\hline $\begin{array}{l}\text { Nephrotic } \\
\text { syndrome }\end{array}$ & & & & & & 0.5902 \\
\hline No & Ref. & $\begin{array}{l}-0.798(-1.114 \\
-0.481) \star \star \star \star\end{array}$ & $\begin{array}{l}-1.028(-1.358 \\
-0.698)^{\star \star *}\end{array}$ & $\begin{array}{l}-1.529(-1.842 \\
-1.216)^{\star \star \star}\end{array}$ & $\begin{array}{l}< \\
0.001\end{array}$ & \\
\hline Yes & Ref. & $-0.276(-2.391,1.838)$ & $1.109(-1.080,3.298)$ & $-0.017(-2.205,2.172)$ & 0.662 & \\
\hline $\begin{array}{l}\text { Chronic } \\
\text { kidney } \\
\text { disease }\end{array}$ & & & & & & 0.932 \\
\hline No & Ref. & $-0.703(-1.111,-0.295)^{\star \star \star}$ & $-0.955(-1.372,-0.538)^{\star \star \star}$ & $-1.491(-1.888,-1.093)^{\star \star \star}$ & $<0.001$ & \\
\hline Yes & Ref. & 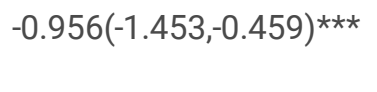 & $-1.116(-1.652,-0.581)^{\star \star \star}$ & $-1.568(-2.072,-1.064)^{\star \star \star}$ & $<.001$ & \\
\hline Sepsis & & & & & & 0.036 \\
\hline No & Ref. & $-0.697(-1.029,-0.365)^{\star \star \star}$ & $-0.911(-1.254,-0.567)^{\star \star \star}$ & 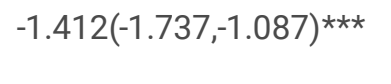 & $\begin{array}{l}< \\
0.001\end{array}$ & \\
\hline Yes & Ref. & $-1.333(-2.458,-0.207) \star$ & $-1.520(-3.000,-0.041) *$ & $-1.927(-3.823,-0.030) *$ & 0.006 & \\
\hline $\begin{array}{l}* \mathrm{P}<0.05, * * \mathrm{P} \\
\text { interaction } \mathrm{W} \\
\text { disease and } \\
\text { ICU; ICU, inte }\end{array}$ & $\begin{array}{l}.01, * \star \star \\
\text { present } \\
\text { sis with } \\
\text { ve care }\end{array}$ & $\begin{array}{l}0.001 \text {; } \mathrm{P} \text { for trend was pr } \\
\text { as the interaction of age, } \\
\text { rum albumin } \text { initial }_{\text {on leng }} \\
; \mathrm{Cl} \text {, confidence interval. }\end{array}$ & $\begin{array}{l}\text { ented as comparison of } \\
\text { ander, malignancy, liver c } \\
\text { of ICU stay; albumin }\end{array}$ & $\begin{array}{l}\text { uartile of albumin } \\
\text { hositial in } \\
\text { hosis, nephrotic syndrom } \\
\text { the first serum albumin le }\end{array}$ & $\begin{array}{l}\text { group } \\
\text { chronic } \\
\text { I when }\end{array}$ & $\begin{array}{l}\text { P } \\
\text { idney } \\
\text { ttering the }\end{array}$ \\
\hline
\end{tabular}

\section{Discussion}




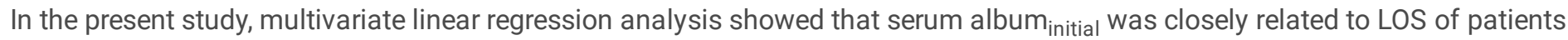
with AHF. Trend test and smooth curve fittings suggested that LOS was gradually shorten when serum albumin initial $_{\text {level was }}$ gradually increased (based on serum albumin being less than its maximum; maximum albumin initial $: 5.1 \mathrm{~g} / \mathrm{dl}$ ). in our subgroups,

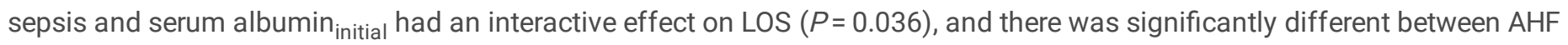
patients with sepsis ( $\beta:-1.927 ; 95 \% \mathrm{Cl}:-3.823,-0.030)$ and without sepsis( $\beta:-1.412 ; 95 \% \mathrm{Cl}:-1.737,-1.087)$.

The nutritional status of patients with AHF in ICU significantly affects their prognosis and LOS, albumin not only maintains the colloidal osmotic pressure, but also plays an important role in their nutritional status. Hypoalbuminemia, occurred commonly in patients with AHF in ICU, might be related to their poorer heart function and more underlying diseases, and it could result in serious adverse events. Previous studies showed that hypoalbuminemia significantly affected prognosis and LOS of various diseases, such as patients for severe sepsis, acute decompensated chronic obstructive pulmonary disease and requiring surgery.[10-13] But none of them proposed the specific relationship between albumin and LOS. In the present study, negative relationships between serum albumin and LOS in patients with AHF was found, and elevation of serum albumin level could reduce the LOS. Serum albumin could maintains the colloidal osmotic pressure, the proper serum albumin is beneficial to the recovery oh AHF patients, however, with the levels of serum albuminas increasing, heart load will inevitably be aggravated, the topic on the optimical value of serum albuminas has not been widely explored. the further increases of albumin might weight the heart load, which may be not conducive to the prognosis of patients with AHF. Therefore, the above findings were based on the fact that albumin is less than $5.1 \mathrm{~g} / \mathrm{dl}$.

Currently, several studies had suggested that serum albumin level $<3.5 \mathrm{~g} / \mathrm{dL}$ was an independent risk factor for prolonged LOS,[1214] Clinicians are more inclined to treat moderate and severe hypoalbuminemia, but albumin level are divided into normal albumin levels ( $\geq 3.5 \mathrm{~g} / \mathrm{dl})$, mild hypoalbuminemia $(3.0 \mathrm{~g} / \mathrm{dl}-3.5 \mathrm{~g} / \mathrm{dl})$, moderate hypoalbuminemia $(2.5 \mathrm{~g} / \mathrm{dl}-3.0 \mathrm{~g} / \mathrm{dl})$ and severe hypoalbuminemia $(<2.5 \mathrm{~g} / \mathrm{dl})$. The present study found that compared with low albumin level, high albumin level could significantly reduce the LOS. Therefore, the treatment of mild albuminemia is also vital to shorten the LOS.

Age and gender are important indicators for risk stratification and treatment of patients with AHF. Previous literature demonstrated that age not only was an independent risk factor for mortality of various diseases, but also determined the length of their hospital stay, and with age increasing, LOS was prolonged.[15-17] This might be because the elderly in ICU often had multiple organ failure, including poor heart function and other serious underlying diseases, which lead to poor prognosis and long LOS. For gender, women may be closely related to longer LOS.[18] Compared with men, female had higher systolic blood pressure, and the article published by redfield et al. on circulation thought as patients grew older, female could have heavier arteriosclerosis.[19, 20] Severe coronary arteriosclerosis reduced blood supply of heart, and made prognosis of patients with AHF worse. In our study, neither of different age and gender had an impact on the relationship between serum albumin and LOS.

For AHF patients with malignancy, liver cirrhosis, nephrotic syndrome, chronic kidney disease and sepsis, these comorbidities can affect the synthesis and concentration of albumin.[21-24] In subgroup analysis, it can be found that only sepsis had an impact on the relationship between serum albumin and LOS. Sepsis is systemic infectious disease that often leads to dysfunction of various organs of the body. Demissei et al. pointed out AHF patients often had elevated inflammation indicators and had poor prognosis, [25] but there is currently no clear guideline for the treatment of AHF patients with sepsis.[26] In the present study, we found that compared to without sepsis, serum albumin can significantly reduce the LOS in AHF patients with sepsis, which might guide clinical practice. Explanation from the clinical mechanism, serum albumin enhances immunity, regulates inflammation and reduces oxidative damage, which are beneficial to reduce the damage of sepsis to various organs of the body.

The present study found that high serum albumin level was beneficial to shorten LOS of AHF patients, and the result could guide clinicians to reduce LOS of AHF patients by changing albumin levels. However, our study also have some limitations. Firstly, The maximum serum albumin $_{\text {initial }}$ level included in our study was $5.1 \mathrm{~g} / \mathrm{dl}$. When the albumin level is greater than $5.1 \mathrm{~g} / \mathrm{dl}$, whether the relationship between serum albumin and LOS is still negative has not been studied. Secondly, the study was a single-center retrospective design, the numbers of patients included are not large, and the selected population is relatively limited. Finally, we might not adjust other potential confounding factors.

\section{Conclusion}


When serum albumin was less than $5.1 \mathrm{~g} / \mathrm{dl}$, the negative association was presented between serum albumin level and LOS among patients with AHF, and this association is even closer in patients with sepsis, and it maybe guide clinical treatments and judge prognosis.

\section{Abbreviations}

LOS: length of stay

ICU: the intensive care unit

heart failure: HF

the medical information mart for intensive care IV: MIMIC-IV

systolic blood pressure: SBP

diastolic blood pressure: DBP

body mass index: BMI

confidence interval: $\mathrm{Cl}$

\section{Declarations}

Ethics approval: Ethics approval Laboratory for Computational Physiology at the Massachusetts Institute of Technology.

Patient consent Obtained.

Availability of data and materials The data of the present investigation were from MIMIC-IV database(https://mimic.mit.edu/)

Competing interests: None declared.

Funding: This study was supported by the Jiangsu Provincial Science and Technology Department Social Development Fund (BE2019639) and Jiangsu Provincial Health Commission Project Fund (M2020015)

Contributors: TL was mainly responsible for extraction of data and writing of the manuscript, LLW, XQL, ZHL, ZXT, HCX and CFW was responsible for data processing and collection; JHC was responsible for reviewing the literature; TDX and DYL contributed to their support and guidance in article design and writing.

Acknowledgements Thanks to all the staff of MIMIC-IV.

\section{References}

1. Ponikowski P, Voors AA, Anker SD, Bueno H, Cleland J, Coats A, Falk V, González-Juanatey JR, Harjola VP, Jankowska EA et al: 2016 ESC Guidelines for the diagnosis and treatment of acute and chronic heart failure: The Task Force for the diagnosis and treatment of acute and chronic heart failure of the European Society of Cardiology (ESC)Developed with the special contribution of the Heart Failure Association (HFA) of the ESC. EUR HEART J 2016, 37(27):2129-2200.

2. Tanık VO, Çınar T, Karabağ Y, Şimşek B, Burak $C$, Çağdaş $M$, Rencüzoğulları İ. The prognostic value of the serum albumin level for long-term prognosis in patients with acute pulmonary embolism. CLIN RESPIR J. 2020;14(6):578-85.

3. Zhang J, Zhang R, Wang Y, Li H, Han Q, Wu Y, Wang T, Liu F: The Level of Serum Albumin Is Associated with Renal Prognosis in Patients with Diabetic Nephropathy. J DIABETES RES 2019, 2019:7825804.

4. Kim YS, Sol IS, Kim MJ, Kim SY, Kim JD, Kim YH, Kim KW, Sohn MH, Kim KE. Serum Albumin as a Biomarker of Poor Prognosis in the Pediatric Patients in Intensive Care Unit. Korean J Crit Care Med. 2017;32(4):347-55. 
5. Prenner SB, Pillutla R, Yenigalla S, Gaddam S, Lee J, Obeid MJ, Ans AH, Jehangir Q, Kim J, Zamani P et al: Serum Albumin Is a Marker of Myocardial Fibrosis, Adverse Pulsatile Aortic Hemodynamics, and Prognosis in Heart Failure With Preserved Ejection Fraction. J AM HEART ASSOC 2020, 9(3):e14716.

6. Ancion A, Allepaerts S, Robinet S, Oury C, Pierard LA, Lancellotti P. Serum albumin level and long-term outcome in acute heart failure. ACTA CARDIOL. 2019;74(6):465-71.

7. El IM, El KB, Murtaza G, Paul TK, Refaat MM. Prognostic role of albumin level in heart failure: A systematic review and metaanalysis. Med (Baltim). 2021;100(10):e24785.

8. Arques S, Roux E, Stolidi P, Gelisse R, Ambrosi P. Usefulness of serum albumin and serum total cholesterol in the prediction of hospital death in older patients with severe, acute heart failure. ARCH CARDIOVASC DIS. 2011;104(10):502-8.

9. Ñamendys-Silva SA, González-Herrera MO, Texcocano-Becerra J, Herrera-Gómez A. Hypoalbuminemia in critically ill patients with cancer: incidence and mortality. Am J Hosp Palliat Care. 2011;28(4):253-7.

10. Caironi P, Tognoni G, Masson S, Fumagalli R, Pesenti A, Romero M, Fanizza C, Caspani L, Faenza S, Grasselli G et al: Albumin replacement in patients with severe sepsis or septic shock. N Engl J Med 2014, 370(15):1412-1421.

11. Wang Y, Stavem K, Dahl FA, Humerfelt S, Haugen T. Factors associated with a prolonged length of stay after acute exacerbation of chronic obstructive pulmonary disease (AECOPD). Int J Chron Obstruct Pulmon Dis. 2014;9:99-105.

12. Rady MY, Ryan T, Starr NJ. Clinical characteristics of preoperative hypoalbuminemia predict outcome of cardiovascular surgery. JPEN J Parenter Enteral Nutr. 1997;21(2):81-90.

13. Rich MW, Keller AJ, Schechtman KB, Marshall WJ, Kouchoukos NT. Increased complications and prolonged hospital stay in elderly cardiac surgical patients with low serum albumin. AM J CARDIOL. 1989;63(11):714-8.

14. Sricharoen P, Phinyo P, Patumanond J, Piyayotai D, Sittichanbuncha Y, Yuksen C, Likittanasombat K, Cheuathonghua E. Clinical Predictors Influencing the Length of Stay in Emergency Department Patients Presenting with Acute Heart Failure. Medicina (Kaunas) 2020, 56(9).

15. Sharif R, Parekh TM, Pierson KS, Kuo YF, Sharma G. Predictors of early readmission among patients 40 to 64 years of age hospitalized for chronic obstructive pulmonary disease. Ann Am Thorac Soc. 2014;11(5):685-94.

16. De la Garza-Ramos R, Goodwin CR, Abu-Bonsrah N, Jain A, Miller EK, Neuman BJ, Protopsaltis TS, Passias PG, Sciubba DM: Prolonged length of stay after posterior surgery for cervical spondylotic myelopathy in patients over $65 y e a r s$ of age. $\mathrm{J}$ CLIN NEUROSCI 2016, 31:137-41.

17. Järvinen $\mathrm{O}$, Huhtala H, Laurikka J, Tarkka MR. Higher age predicts adverse outcome and readmission after coronary artery bypass grafting. WORLD J SURG. 2003;27(12):1317-22.

18. Formiga F, Chivite D, Manito N, Mestre AR, Llopis F, Pujol R. Admission characteristics predicting longer length of stay among elderly patients hospitalized for decompensated heart failure. EUR J INTERN MED. 2008;19(3):198-202.

19. Zsilinszka R, Shrader P, DeVore AD, Hardy NC, Mentz RJ, Pang PS, Peacock WF, Fonarow GC, Hernandez AF. Sex Differences in the Management and Outcomes of Heart Failure With Preserved Ejection Fraction in Patients Presenting to the Emergency Department With Acute Heart Failure. J CARD FAIL. 2016;22(10):781-8.

20. Redfield MM, Jacobsen SJ, Borlaug BA, Rodeheffer RJ, Kass DA. Age- and gender-related ventricular-vascular stiffening: a community-based study. CIRCULATION. 2005;112(15):2254-62.

21. Metgud R, Patel S. Serum and salivary levels of albumin as diagnostic tools for oral pre-malignancy and oral malignancy. BIOTECH HISTOCHEM. 2014;89(1):8-13.

22. Bernardi M, Ricci CS, Zaccherini G. Role of human albumin in the management of complications of liver cirrhosis. J Clin Exp Hepatol. 2014;4(4):302-11.

23. Yoshimoto S, Nagai K, Shibata E, Ueda S, Ono H, Tamaki M, Nishimura K, Obata F, Inagaki T, Minato M et al: Influential factors on serum albumin concentration in hospitalized chronic kidney disease patients. J Med Invest 2017, 64(1.2):146-152.

24. Qian SY, Liu J. [Relationship between serum albumin level and prognosis in children with sepsis, severe sepsis or septic shock]. Zhonghua Er Ke Za Zhi. 2012;50(3):184-7.

25. Demissei BG, Cleland JG, O'Connor CM, Metra M, Ponikowski P, Teerlink JR, Davison B, Givertz MM, Bloomfield DM, Dittrich H et al: Procalcitonin-based indication of bacterial infection identifies high risk acute heart failure patients. INT J CARDIOL 2016, 204:164-171.

Page $10 / 12$ 


\section{Figures}

\section{Patients with acute heart failure} from MIMMI-IV database

Patients were not first hospital and not first ICU admissions ( $\mathrm{n}=19483)$

Patients with acute heart failure $(\mathrm{n}=5080)$

Finally, patients were enrolled $(\mathrm{n}=2280)$

Figure 1

Flow chart of being included patients with acute heart failure. 
(A)

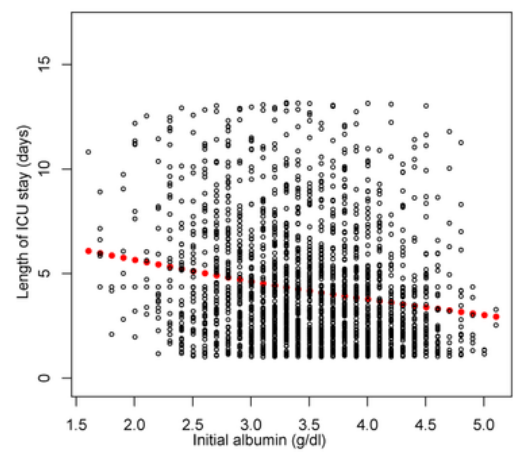

(C)

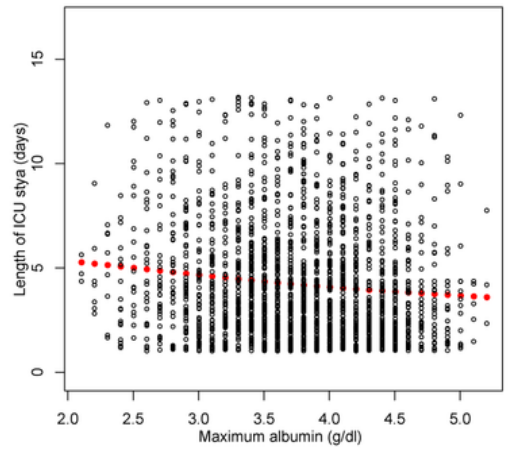

$(\mathrm{E})$

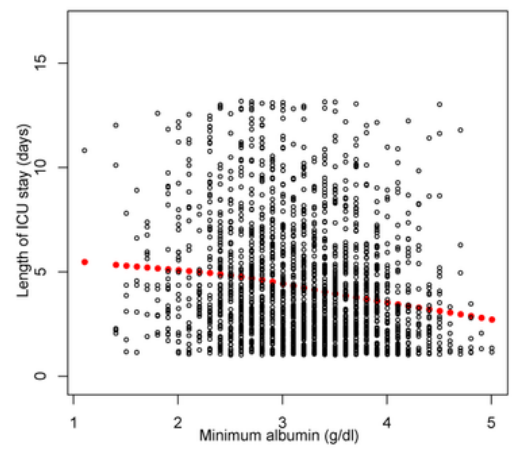

(B)

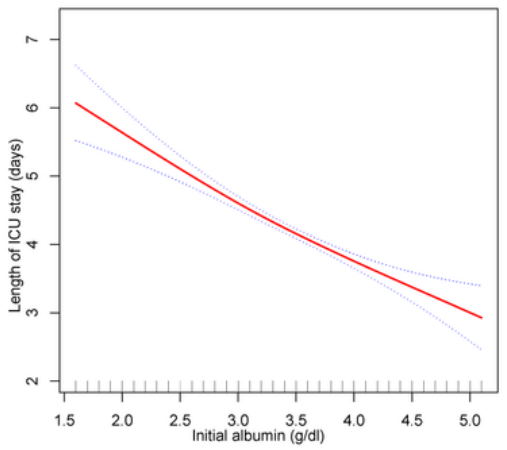

(D)

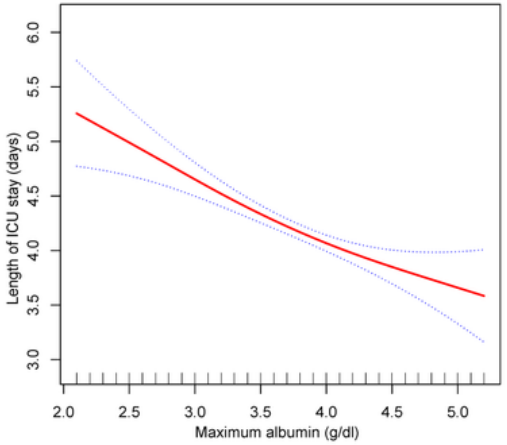

$(\mathrm{F})$

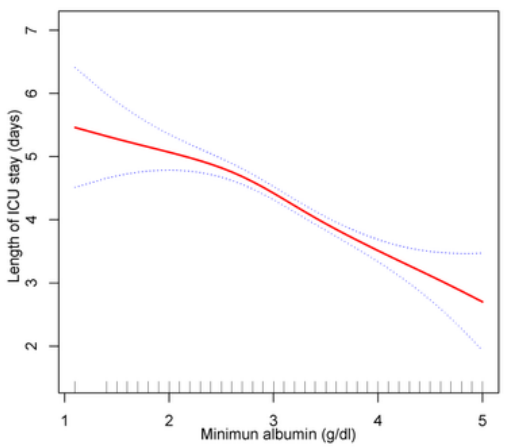

Figure 2

The association between serum albumin with length of ICU stay. Each black point represents a patient with acute heart failure in ICU. The upper and lower blue dashed lines represent $95 \% \mathrm{Cl}$ of serum albumin. A continuous red line indicates the level of serum albumin. (A) and (B) showed the relationship between albumininitial and length of ICU stay. (C) and (D) showed the relationship between albuminmin and length of ICU stay. $(E)$ and $(F)$ showed the relationship between albuminmax and length of ICU stay. albumininitial, the first serum albumin level when entering the ICU; albuminmin, minimum albumin level during ICU; albuminmax, maximum albumin level during ICU; ICU, intensive care unit.

\section{Supplementary Files}

This is a list of supplementary files associated with this preprint. Click to download.

- AppendixTableA1.pdf

- AppendixTableA2.docx

- AppendixTableA3.docx 